\title{
Problem Solving Behaviors of Grade Seven Students Focusing on Negative Integers
}

\author{
Su'idah Nur Aini Aziz, Yusuf Fuad, Rooselyna Ekawati \\ Program Pascasarjana, Department of Mathematics, Universitas Negeri Surabaya, Ketintang, Surabaya 60231, East \\ Java, Indonesia \\ suidahaziz16070785012@mhs.unesa.ac.id
}

\begin{abstract}
Problem solving behavior play an important role for any student because problem solving behavior can given provided description of the student's behavior during the process of solving the mathematics problem. This study investigate student problem solving behavior when solving the negative integers problems. Subjects in this study were the $7^{\text {th }}$ grade students of SMPN 2 Bangkalan, consists of 12 girls and 15 boys. All students were given mathematical ability test and three questions of word problem test that was related to addition and subtraction of negative integers. Three subjects were volunteerly selected with different mathematics ability namely high, medium and low mathematic ability for deep interview of mathematical problem solving behavior in solving negative integers. The results of this study assessed that the behavior of problem solving of a subject with high ability include the Meaning-Based Approachjustification (MBA-j) category. Behavior of subject with medium categorized as Direct Translation Approach-proficient (DTA-p), and the behavior of subject with low ability is included in the category of Direct Translation Approach-not proficient (DTA-p)
\end{abstract}

Keywords- Problem solving behavior, negative integers.

\section{INTRODUCTION}

Integers are the main capital for junior high school students to understand concepts in arithmetic [1, 2]. In fact many students still find it difficult to understand the concept of integers especially negative integers because students experience cognitive conflicts about the understanding of negative integers. One possible reason for the variability in students' integer understanding is their interpretation of integer notation [3]. Many students still have difficulties in understanding negative integers, because symbol "-" has three meanings: unary (negative), binary (subtraction), and symmetric (opposite) [3, 4]. The above is certainly a problem that needs to be addressed and improved, because there are still many students who do not understand the concept of negative integers. Therefore needed a special understanding to helping students in learning mathematics, because understanding of integers is very important for students to succeed in mathematics [1]. According [5] Learning mathematics with understanding is an important instructional goal for all students. That the primary goals of mathematics learning are understanding and problem solving, and that these goals are inextricably related because learning mathematics with understanding is best supported by engaging in problem solving [6].

Problem solving ability is one of important goals in learning mathematics. Developing students' problem-solving abilities is a primary objective of instructions [7]. Indeed, solving mathematical problems which are closely related mathematics problem solving with understanding of mathematical concepts. To become successful problem solver, an individual must have an ample relevant experience in learning mathematics and solving related problems, strong content knowledge, proficiency in using a variety of representations and a solid grasp of how to recognize and construct patterns of inference [7]. When solving the problem, the most important thing besides the result of problem solving is the problem solving behavior, since the problem solving behavior provided description of the student's behavior during the process of solving the mathematics problem. Automatic assessment of problem solving processes for large populations; this will aid both instructors and researchers to better understand students' behavior [8]. Problem solving behavior in mathematics is an individual activity that is often shown in solving mathematics problems.

At the time of solving mathematics problem, the behavior shown by the students when determining the solution of the problem is clearly different, because the ability of each student are not the same. This is supported by research conducted by Tjoe that there are differences in problem solving behavior of students with high ability and students with medium ability [9]. According [10] problem solving behavior are grouped in two categories, i.e: (1) Direct Translation Approach (DTA), and (2) Meaning-Based Approach (MBA). Direct Translation Approach (DTA) was further divided into three subcategories, i.e: (1) Direct Translation Approach-proficient (DTA-p), (2) Direct Translation Approach-not proficient (DTA-np), (3) Direct Translation Approach-limited context (DTA-lc). Whereas Meaning-Based Approach (MBA) was further divided into two subcategories, i.e: (1) Meaning-Based Approach-full 
context (MBA-fc), and (2) Meaning-Based Approachjustification (MBA-j).

\section{METHOD}

\section{A. Partisipant}

This study applied a descriptive-qualitative approach that aimed to investigate student problem solving behavior when solving the negative integers problems. Subjects in this study were the $7^{\text {th }}$ grade students of SMPN 2 Bangkalan consists of 12 girls and 15 boys. All students were given mathematical ability test and three questions of word problem test that was related to addition and subtraction of negative integers. Three subjects were volunteerly selected with different mathematics ability namely high, medium, and low mathematics ability.

\section{B. Analysis}

Data was obtained from mathematical ability test and problem solving behavior test as well as semi-structured interview based on problem solving behavior test. The First, grade 7 students were given mathematical ability test then three days later given the problem solving behavior test after it was selected three students with different abilities based on result mathematics ability test and problem solving behavior test to next conducted semi-structured interview based on problem solving behavior test. Interviews were conducted only on three subjects of high, medium and low mathematical ability to explore more deeply about problem solving behavior. Here is the category of problem solving behavior.

\section{Direct Translation Approach (DTA)}

The DTA category is characterized by students' lack of evidence of transformation of problem information or use of problem context, including all references to the units and relationships between the elements of the problem. These students refer to and/or record elements of the problem without the appropriate context provided in the problem. They reiterate the given numbers without relevant context or repeatedly reread individual sentences without recording or transforming the given information. Finally, one subcategory of the students carries out mathematical computations without referring to or rereading the problem's text [10]. This category was further divided into three subcategories, i.e: (1) Direct Translation Approach-proficient (DTA-p), (2) Direct Translation Approach-not proficient (DTA-np), (3) Direct Translation Approach-limited context (DTA-lc).

\section{Meaning-Based approach $(M B A)$}

The MBA category is characterized by students' transformative behavior, which has three defining characteristics: recording given information, use of context, and provision of explanations and/or justifications for mathematical operations. One of the predominant behaviors of these students is recording the given information with the appropriate context, which organizes the information to support the solution process. In addition, these students provide an explanation for the computational steps performed. One subcategory is characterized by provision of both explanations and justifications for the computational steps. Finally, the students' statements of the answers reveal an understanding of their meaning or relevance to the problem [10]. This larger category was further subdivided into two subcategories, i.e: (1) Meaning-Based Approach-full context (MBA-fc), and (2) Meaning-Based Approach-justification (MBA-j).

Each indicator in every category will be depicted on the following table:

\section{TABLE I. INDICATOR FOR PROBLEM SOLVING BEHAVIORS}

\begin{tabular}{|c|c|c|c|c|c|}
\hline Aspect & DTA-p & DTA-np & DTA-lc & $M B A-f c$ & $M B A-j$ \\
\hline $\begin{array}{l}\text { Fluency of } \\
\text { Declaring } \\
\text { the } \\
\text { questions } \\
\text { that have } \\
\text { been read } \\
\text { using the } \\
\text { sentence } \\
\text { itself }\end{array}$ & Unfluently & Unfluently & Unfluently & Fluently & Fluently \\
\hline $\begin{array}{l}\text { Relevance } \\
\text { of } \\
\text { mentioning } \\
\text { what is } \\
\text { known and } \\
\text { what is } \\
\text { asked in the } \\
\text { problem }\end{array}$ & Relevant & Unrelevant & Relevant & Relevant & Relevant \\
\hline $\begin{array}{l}\text { Logical } \\
\text { basic used } \\
\text { in linking } \\
\text { information }\end{array}$ & Illogical & Illogical & Illogical & $\begin{array}{l}\text { Part } \\
\text { Logical }\end{array}$ & Logical \\
\hline $\begin{array}{l}\text { The } \\
\text { effectiveness } \\
\text { of the used } \\
\text { strategies }\end{array}$ & Ineffective & Ineffective & Effective & Effective & Effective \\
\hline $\begin{array}{l}\text { Write down } \\
\text { the final } \\
\text { answer as a } \\
\text { solution }\end{array}$ & $\begin{array}{l}\text { Not in } \\
\text { context }\end{array}$ & $\begin{array}{l}\text { Not in } \\
\text { context }\end{array}$ & In context & In context & $\begin{array}{l}\text { In } \\
\text { context }\end{array}$ \\
\hline $\begin{array}{l}\text { Given } \\
\text { Reasoning } \\
\text { and } \\
\text { Justification }\end{array}$ & Unrelevant & Unrelevant & Unrelevant & Unrelevant & Relevant \\
\hline
\end{tabular}

\section{RESULTS}

Mathematical ability test and problem solving behavior test have been analyzed for later categorized in each of high, medium and low ability. Based on the results of the analysis there were 8 students with high ability, 10 students with medium ability and 9 students with low ability. From the category of mathematics ability of students, chosen each one of the students to be as subjects. PSH = Problem Solving Behavior of Student With High Ability, PSM = Problem Solving Behavior of Student With Medium Ability, PSL = Problem Solving Behavior Of Student With Low Ability 
TABEL II. RESULT OF PROBLEM SOLVING BEHAVIOR

\begin{tabular}{|c|c|c|c|c|c|c|c|c|}
\hline \multirow{2}{*}{$\begin{array}{l}\text { Studen } \\
\text { ts of } \\
\text { Study }\end{array}$} & \multirow{2}{*}{$\begin{array}{c}\text { Ite } \\
\text { m } \\
\text { test }\end{array}$} & \multicolumn{6}{|c|}{ Indicator for Problem Solving Behavior } & \multirow{2}{*}{$\begin{array}{c}\text { Catego } \\
\text { ries of } \\
\text { Behavi } \\
\text { or } \\
\end{array}$} \\
\hline & & $\begin{array}{c}\text { Indi } \\
\text { cato } \\
\text { r-1 }\end{array}$ & $\begin{array}{c}\text { Indi } \\
\text { cato } \\
\text { r-2 }\end{array}$ & $\begin{array}{c}\text { Indi } \\
\text { cato } \\
\text { r-3 }\end{array}$ & $\begin{array}{c}\text { Indi } \\
\text { cato } \\
r-4\end{array}$ & $\begin{array}{c}\text { Indi } \\
\text { cato } \\
\text { r-5 }\end{array}$ & $\begin{array}{c}\text { Indi } \\
\text { cato } \\
r-6\end{array}$ & \\
\hline \multirow{3}{*}{ PSH } & 1 & $\begin{array}{l}\text { Flue } \\
\text { ntly }\end{array}$ & $\begin{array}{l}\text { Rele } \\
\text { vant }\end{array}$ & $\begin{array}{l}\text { Logi } \\
\text { cal }\end{array}$ & $\begin{array}{l}\text { Effec } \\
\text { tive }\end{array}$ & $\begin{array}{l}\text { In } \\
\text { conte } \\
\text { xt }\end{array}$ & $\begin{array}{l}\text { Rele } \\
\text { vant }\end{array}$ & $\begin{array}{l}\text { MBA- } \\
\text { justifica } \\
\text { tion }\end{array}$ \\
\hline & 2 & $\begin{array}{l}\text { Flue } \\
\text { ntly }\end{array}$ & $\begin{array}{l}\text { Rele } \\
\text { vant }\end{array}$ & $\begin{array}{l}\text { Logi } \\
\text { cal }\end{array}$ & $\begin{array}{l}\text { Effec } \\
\text { tive }\end{array}$ & $\begin{array}{l}\text { In } \\
\text { conte } \\
\mathrm{xt}\end{array}$ & $\begin{array}{l}\text { Rele } \\
\text { vant }\end{array}$ & $\begin{array}{l}\text { MBA- } \\
\text { justifica } \\
\text { tion }\end{array}$ \\
\hline & 3 & $\begin{array}{l}\text { Flue } \\
\text { ntly }\end{array}$ & $\begin{array}{l}\text { Rele } \\
\text { vant }\end{array}$ & $\begin{array}{l}\text { Logi } \\
\text { cal }\end{array}$ & $\begin{array}{l}\text { Effec } \\
\text { tive }\end{array}$ & $\begin{array}{l}\text { In } \\
\text { conte } \\
\text { xt }\end{array}$ & $\begin{array}{l}\text { Rele } \\
\text { vant }\end{array}$ & $\begin{array}{l}\text { MBA- } \\
\text { justifica } \\
\text { tion }\end{array}$ \\
\hline \multirow{3}{*}{ PSM } & 1 & $\begin{array}{l}\text { Flue } \\
\text { ntly }\end{array}$ & $\begin{array}{l}\text { Rele } \\
\text { vant }\end{array}$ & $\begin{array}{l}\text { Illogi } \\
\text { cal }\end{array}$ & $\begin{array}{l}\text { Ineff } \\
\text { ectiv } \\
\text { e }\end{array}$ & $\begin{array}{l}\text { Not } \\
\text { in } \\
\text { conte } \\
\text { xt }\end{array}$ & $\begin{array}{l}\text { Unre } \\
\text { levan } \\
\mathrm{t}\end{array}$ & $\begin{array}{l}\text { DTA- } \\
\text { proficie } \\
\text { nt }\end{array}$ \\
\hline & 2 & $\begin{array}{l}\text { Flue } \\
\text { ntly }\end{array}$ & $\begin{array}{l}\text { Rele } \\
\text { vant }\end{array}$ & $\begin{array}{l}\text { Part } \\
\text { Logi } \\
\text { cal }\end{array}$ & $\begin{array}{l}\text { Effec } \\
\text { tive }\end{array}$ & $\begin{array}{l}\text { In } \\
\text { conte } \\
\text { xt }\end{array}$ & $\begin{array}{l}\text { Unre } \\
\text { levan } \\
\mathrm{t}\end{array}$ & $\begin{array}{l}\text { DTA- } \\
\text { limited } \\
\text { context }\end{array}$ \\
\hline & 3 & $\begin{array}{l}\text { Flue } \\
\text { ntly }\end{array}$ & $\begin{array}{l}\text { Rele } \\
\text { vant }\end{array}$ & $\begin{array}{l}\text { Illogi } \\
\text { cal }\end{array}$ & $\begin{array}{l}\text { Ineff } \\
\text { ectiv } \\
\text { e }\end{array}$ & $\begin{array}{l}\text { Not } \\
\text { in } \\
\text { conte } \\
\text { xt } \\
\end{array}$ & $\begin{array}{l}\text { Unre } \\
\text { levan } \\
\mathrm{t}\end{array}$ & $\begin{array}{l}\text { DTA- } \\
\text { proficie } \\
\text { nt }\end{array}$ \\
\hline \multirow{3}{*}{ PSL } & 1 & $\begin{array}{l}\text { Flue } \\
\text { ntly }\end{array}$ & $\begin{array}{l}\text { Unre } \\
\text { levan } \\
\mathrm{t}\end{array}$ & $\begin{array}{l}\text { Illogi } \\
\text { cal }\end{array}$ & $\begin{array}{l}\text { Ineff } \\
\text { ectiv } \\
\text { e }\end{array}$ & $\begin{array}{l}\text { Not } \\
\text { in } \\
\text { conte } \\
\text { xt }\end{array}$ & $\begin{array}{l}\text { Unre } \\
\text { levan } \\
\mathrm{t}\end{array}$ & $\begin{array}{l}\text { DTA- } \\
\text { not } \\
\text { profoci } \\
\text { ent }\end{array}$ \\
\hline & 2 & $\begin{array}{l}\begin{array}{l}\text { Flue } \\
\text { ntly }\end{array} \\
\text {. }\end{array}$ & $\begin{array}{l}\text { Rele } \\
\text { vant }\end{array}$ & $\begin{array}{l}\text { Illogi } \\
\text { cal }\end{array}$ & $\begin{array}{l}\text { Effec } \\
\text { tive }\end{array}$ & $\begin{array}{l}\text { In } \\
\text { conte } \\
\text { xt }\end{array}$ & $\begin{array}{l}\text { Unre } \\
\text { levan } \\
\mathrm{t}\end{array}$ & $\begin{array}{l}\text { DTA- } \\
\text { limited } \\
\text { context }\end{array}$ \\
\hline & 3 & $\begin{array}{l}\text { Flue } \\
\text { ntly }\end{array}$ & $\begin{array}{l}\text { Unre } \\
\text { levan } \\
\mathrm{t}\end{array}$ & $\begin{array}{l}\text { Illogi } \\
\text { cal }\end{array}$ & $\begin{array}{l}\text { Ineff } \\
\text { ectiv } \\
\text { e }\end{array}$ & $\begin{array}{l}\text { Not } \\
\text { in } \\
\text { conte } \\
\text { xt } \\
\end{array}$ & $\begin{array}{l}\text { Unre } \\
\text { levan } \\
\mathrm{t}\end{array}$ & $\begin{array}{l}\text { DTA- } \\
\text { not } \\
\text { profoci } \\
\text { ent }\end{array}$ \\
\hline
\end{tabular}

Table 2 shows that problem solving behavior of each student on item test. Behavior of students with high mathematics ability on item test 1,2 , and 3 include the MBAJustification category. Behavior of students with medium mathematics ability on item test 1 and 3 include in the category of DTA-proficient category, whereas on item test 2 categorized as DTA-limited context category. Behavior of students with low mathematics ability on item test 1 and 3 include the DTA-not profecient category, whereas on item test 2 include in the category of DTA-limited context category.

\section{A. Problem Solving Behavior of Students with High Ability (PSH)}

Students with high ability strategy when solving negative integer problems using concept of a number line. Figure 1 and Figure 2 show the results of the PSH students' answers.

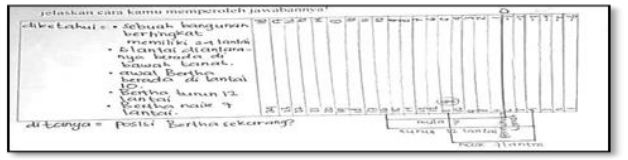

Figure 1. Answered Item Test 1

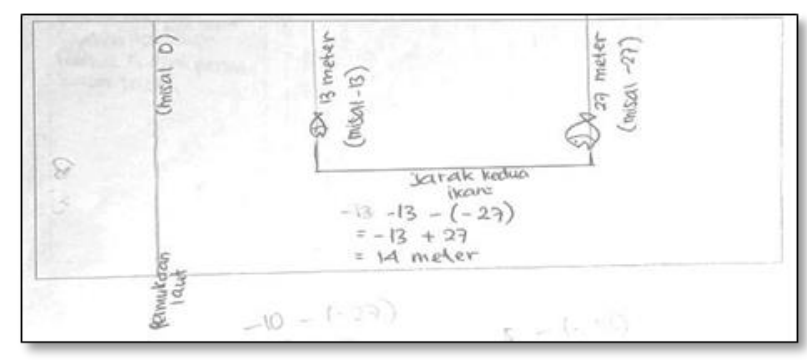

Figure 2: Answer Item Test 3

From the results of problem solving behavior test answers, PSH students used the concept of the number line when completing the test, in Figure 1 PSH students wrote that the ground surface is equal to 0 on the number line. When the "up" are enumerated the summing operation and the "down" is supposed operation of the reduction. In figure 2 PSH students write that sea level is equal to 0 , so that when the fish position is below sea level, PSH students draw fish positions below number line. In the item test 3 PSH does not write down that is known and asked, because at the time of reading test the student directly write that is known on the line of numbers and immediately complete the test. However, when interviews with PSH students related to the known and asked on the item test 3 students PSH answered with relevance. The following interviews with students PSH:

$\mathrm{R} \quad$ : What is known in item test 3 ?

PSH : Small fish are 13 meters below sea level, and large fish are 27 meters below sea level.

$\mathrm{R} \quad$ : What is being asked?

PSH : The distance between the two fish

$\mathrm{R} \quad$ : Why do not you write down the known and asked questions?

PSH : Because I directly answer on the answer sheet provided.

R : What Strategy do you use to solve the problem?

$\mathrm{PSH}$ : Using a number line

$\mathrm{R} \quad$ : Why use a number line?

$\mathrm{PSH}$ : Because I think it is easier to solve the problem

Based on the results of interviews conducted by researchers with PSH students, the problem solving behavior shown by PSH tends to read the problem using the sentence itself Fluently, write the known and asked relevant, relate the information, using an effective strategy that is using the concept number line, write the final answer in context and give the reason and justification for each step of the calculation. This behaviors includes MBA-justification category. 
B. Problem Solving Behavior of Students with Medium Ability (PSM)

Student with medium ability strategy while solving negative integer problems using the concept of a number line. Here are the results of PSM student's answer.

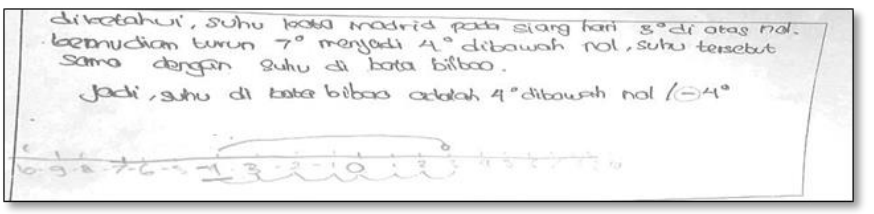

Figure 3: Answered Item Test 3

When the PSM student completes item test 2, the PSM student writes the known and immediately writes the answer without writing the asked one. He used way the concept of the number line. At the interview the PSM students explained that number line is the easiest way. Following interview with student of PSM:

$\mathrm{R} \quad$ : What is known in item test 2?

PSM : Temperatures in madrid city $3^{\circ}$ above zero. Then down $7^{\circ}$ to $4^{\circ}$ it will be equal to the temperature in bilbao.

R : What was asked on item test 2?

PSM : Temperature in bilbao city

$\mathrm{R} \quad$ : How do you complete the test item 2?

PSH : 3-7 =-4, I also use the number line

$\mathrm{R} \quad$ : Why use a number line?

PSM : Because number line making it easy at the time of solve the problem.

Based on the results of the interview, the problem solving behavior shown by the PSM tends to read the problem using the sentence itself fluently, write down what is known and asked relevant, the basic logic used in linking information part logical, using an effective strategy that uses the concept of the number line, write the final answer in the context and there is no reason and justification for each step of the calculation. These behaviors are categorized as DTA-limited context.

\section{Problem Solving Behavior of Students with Low Ability (PSL)}

Student with low ability strategy when solving negative integer problem used by directly subtracting. Here's the PSL student's answer.

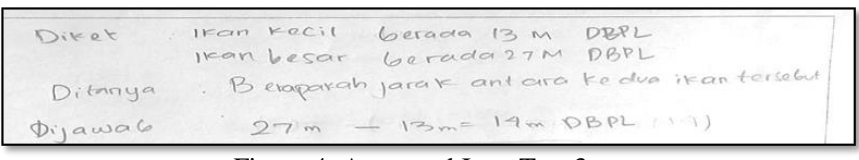

Figure 4: Answered Item Test 3

When solving item test 3, the PSL students wrote down what was known and asked relevantly, but the answer given by PSL students was wrong, because the method used was not in context of the problem. At the time of the interview the PSL students were confused because they did not understand the concept of negative integer operation, so the number under 0 which should be negative she write positive. Performing operations on integers involves signs of required numbers. This makes students get confused and struggle when asked to perform operations on integers [11]. The following interviews were conducted with PSL students:

$\mathrm{R} \quad$ : What way do you use in completing item test 3?

PSL : I just subtracted 27-13=14.

R : Why did you subtract directly?

PSL : Because the question is asked for the distance between the two fish, so I immediately subtract the greatest distance minus the small distance.

$\mathrm{R} \quad$ : What is known in test 3?

PSL : Small fish are 13 meters below sea level and large fish are 27 meters below sea level.

$\mathrm{R}$ : Means the position of fish below sea level you eg positive or negative numbers?

PSL : negative number

$\mathrm{R} \quad$ : why do you answer to write a positive number?

PSL : I'm not sure the answer is the same, because if the numbers below the sea level are negative numbers. Then count back on the answer sheet $(-27-(-13)=-14)$

$\mathrm{R}$ : Now the correct answer, the distance is 14 meters or 14 meters?

PSL : emmhh .. I confused, the answer is -14 meters or 14 meters.

Based on the results of the interview, the problem solving behavior shown by the PSL tends to read about using the sentence itself unfluently, writing down what is known and asked relevant, the basic logic used in linking information illogical, using ineffective strategies, write the final answer not in context and there is no reason and justification for each step of the calculation. The behavior is included in the category of DTA-not proficient.

\section{CONCLUSION}

Based on results of this study assessed that the behavior of problem solving of a subject with high ability tends to read the problem, write the known and asked questions, relate the information, using the relevant strategy, write the final answer, given the reason and justification for each step of calculation. These behaviors include the $M B A-j$ category. Subject with medium ability tends reading the problem, write the known and asked, using unrelevant strategy, write the final answer not in context, there is no reason and justification for each step of the calculation. These behaviors are categorized as DTA- $p$, and subject with low ability tends to re-read questions, write down known and asked questions, lack competence and difficulty in reading problems, understand problems, determine solutions, and perform calculations as well as calculations made less meaningful. The behavior is included in the category of DTA-np. This result gives an idea to the teacher for further use as a consideration in designing the 
learning in accordance with the conditions of the level of understanding and ability of students in solving problems. For further study, it can be done on a larger class with different materials.

\section{ACKNOWLEDGEMENT}

The authors thanks to the 7th grade srudents of SMP Negeri 2 of Bangkalan who have been enthusiasticly involved in this study.

\section{REFERENCES}

[1] D. Akyüz, M. Stephan, and J. K. Dixon, "The role of the teacher in supporting imagery in understanding integers", Egitim ve Bilim, vol. 37, no. 163, pp. 268-282, 2013.

[2] I. Peled, S. Mukhopadhyay, and L. B. Resnick, "Formal and informal sources of mental models for negative numbers. In G. Vergnaud, J. Rogalski, \& M. Artique (Eds.)", Proceedings of the 13th Annual Conference of the International Group for the Psychology of Mathematics Education, vol. 3, pp.106-110, 1989.

[3] L. Bofferding, "Negative Integer Understanding: Characterizing First Graders' Mental Models", Journal for Research in Mathematics Education, vol. 45, no. 2, pp. 194-245, 2014.
[4] J. Vlassis, "The role of mathematical symbols in the development of number conceptualization: The case of the minus sign", Philosophical Psychology, vol. 21, no. 4, pp. 555-570, 2008.

[5] J. S. Andreas and J. S. Gabriel, "Learning mathematics with understanding: A critical consideration of the learning principle in the principles and standards for school mathematics", The Montana Mathematics Enthusiast, vol. 4, no. 1, pp. 103-114, 2007.

[6] V. L. Diana, "Benefits of teaching through problem solving", Teaching Mathematics Through Problem Solving, pp. 4-10, 2009.

[7] K. J. Lester Frank, "Thoughts About Research On Mathematical Problem- Solving Instruction”, The Mathematics Enthusiast, vol. 10, no. 1/2, pp. 245-278, 2013.

[8] L. Moshe and N. Rafi, "Assessing mathematical problem solving behavior in web-based environments using educational data mining", Proceedings of the Chais Conference on Instructional Technologies Research 2013: Learning in the Technological Era, pp. 44-52.

[9] H. H. Tjoe, Which Approaches Do Students Prefer? Analyzing the Mathematical Problem Solving Behavior of Mathematically Gifted Students, (Doctoral Dissertation), 2012, (https://academiccommons.columbia.edu/catalog/ac:161908)

[10] S. J. Pape, "Middle School Children's Behavior: A Cognitive Analysis from a Reading Comprehension Perspective", Journal for Research in Mathematics Education, vol. 35, no. 3, pp. 187-219, 2004.

[11] R. J. Rubin, J. Marcelino, R. Mortel, and M. R. C. Lapinid, "ActivityBased Teaching of Integer Concepts and its Operations", pp. 1-16, 2014. 